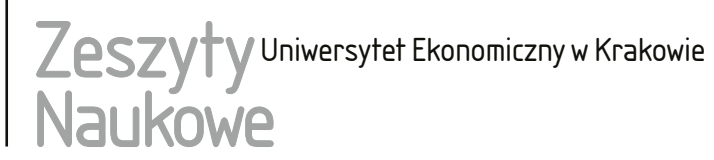

\title{
Pakt stabilności i wzrostu a antycykliczna polityka fiskalna w strefie euro
}

\section{Streszczenie}

Celem artykułu jest ocena roli paktu stabilności i wzrostu w stabilizowaniu gospodarki w strefie euro przez zbadanie współzależności między przestrzeganiem jego reguł przez państwa członkowskie a antycyklicznym nastawieniem ich polityki fiskalnej w latach 1999-2015. W badaniach zastosowano statystykę opisową oraz analizę korelacji. Z przeprowadzonych badań wynikają następujące wnioski: stopień poszanowania reguł paktu stabilności i wzrostu przez państwa członkowskie jest niski, zwłaszcza w odniesieniu do wymogu dotyczącego osiągnięcia i utrzymania średniookresowego celu budżetowego; polityka fiskalna miała raczej charakter procykliczny aniżeli antycykliczny; istnieje dodatnia korelacja między przestrzeganiem numerycznych reguł paktu stabilności i wzrostu a antycyklicznym nastawieniem polityki fiskalnej.

Słowa kluczowe: dyscyplina budżetowa, pakt stabilności i wzrostu, polityka fiskalna, strefa euro.

Klasyfikacja JEL: E62, F15, F45.

\section{Wprowadzenie}

Polityka fiskalna w strefie euro podlega regułom paktu stabilności i wzrostu. Zobowiązuje on państwa członkowskie do osiągnięcia i utrzymania średniookre-

Jan Borowiec, Uniwersytet Ekonomiczny we Wrocławiu, Wydział Nauk Ekonomicznych, Katedra Polityki Ekonomicznej i Europejskich Studiów Regionalnych, ul. Komandorska 118-120, 53-345 Wrocław, e-mail: jan.borowiec@ue.wroc.pl 
sowego celu budżetowego oraz do poszanowania dyscypliny budżetowej. Prowadzenie polityki fiskalnej zgodnie z jego regułami ma zapewnić długookresową stabilność finansów publicznych, wspierającą zrównoważony wzrost gospodarczy, a także zwiększyć możliwości stabilizacyjnego jej oddziaływania na gospodarkę bez ryzyka wystąpienia nadmiernego deficytu.

Celem artykułu jest ocena roli paktu stabilności i wzrostu w stabilizowaniu gospodarki w strefie euro na podstawie analizy współzależności między przestrzeganiem jego reguł przez państwa członkowskie a antycyklicznym nastawieniem ich polityki fiskalnej. Przedmiotem badań są ogólne ramy paktu stabilności i wzrostu, zgodność polityki fiskalnej z jego regułami numerycznymi, antycykliczne nastawienie polityki fiskalnej oraz współzależność między tym nastawieniem a poszanowaniem reguł paktu stabilności i wzrostu. W badaniach zastosowano dwie metody: statystykę opisową oraz analizę korelacji. Badania dotyczą lat 1999-2015. Źródłem danych jest Eurostat oraz bazy danych makroekonomicznych (Ameco) i wskaźników budżetowych Dyrekcji Generalnej ds. Gospodarczych i Finansowych Komisji Europejskiej.

\section{Ogólne ramy paktu stabilności i wzrostu}

Przewidziana w art. 120 Traktatu o funkcjonowaniu Unii Europejskiej (TFUE) koordynacja polityki gospodarczej państw członkowskich powinna zapewniać poszanowanie zasad przewodnich dotyczących stabilnych cen, zdrowych finansów publicznych i warunków pieniężnych oraz trwałej równowagi płatniczej. Podstawą paktu stabilności i wzrostu jest dążenie do zapewnienia zdrowych finansów publicznych jako środka służącego umocnieniu warunków stabilności cen oraz trwałego wzrostu gospodarczego opartego na stabilności finansowej.

Część zapobiegawcza paktu ([Rozporządzenie Rady (WE) nr 1466/97], zmienione przez [Rozporządzenie Parlamentu Europejskiego i Rady (UE) nr 1175/2011)]) wymaga, aby każde państwo członkowskie osiągnęło i utrzymało średniookresowy cel budżetowy dotyczący jego pozycji budżetowej bliskiej równowadze lub nadwyżce. Dlatego też każde państwo należące do strefy euro przedstawia program stabilności, określający średniookresowy cel budżetowy, ścieżkę dostosowawczą prowadzącą do tego celu oraz niezbędne środki. W ramach nadzoru wielostronnego Rada i Komisja badają średniookresowy cel budżetowy przedstawiony przez dane państwo w programie stabilności, a także oceniają, czy ścieżka dostosowawcza prowadząca do tego celu jest właściwa, czy przestrzegane są w ramach tej ścieżki wymogi dotyczące rocznej korekty salda strukturalnego i wzrostu wydatków publicznych oraz czy działania podejmowane lub proponowane są wystarczające do osiągnięcia średniookresowego celu budże- 
towego w trakcie cyklu koniunkturalnego. Wdrażanie programu monitorują Rada i Komisja.

Drugim filarem paktu stabilności i wzrostu jest przewidziana art. 126 TFUE procedura nadmiernego deficytu. Celem tej procedury jest zapobieganie nadmiernym deficytom publicznym oraz - jeśli one wystąpią - doprowadzenie do ich korekty. Jej przebieg przedstawia tabela 1.

Tabela 1. Etapy procedury nadmiernego deficytu

\begin{tabular}{|c|c|}
\hline Traktat TFUE & Etapy procedury nadmiernego deficytu \\
\hline Art. 126 ust. 1 & Państwa członkowskie unikają nadmiernego deficytu \\
\hline Art. 126 ust. 2 & $\begin{array}{l}\text { Komisja nadzoruje rozwój sytuacji budżetowej i wysokość długu publicznego } \\
\text { w państwach członkowskich. Bada ona poszanowanie dyscypliny budżetowej } \\
\text { na podstawie kryterium deficytu i długu publicznego }\end{array}$ \\
\hline Art. 126 ust. 3 & $\begin{array}{l}\text { Jeśli państwo członkowskie nie spełnia wymogów jednego lub obu tych kryte- } \\
\text { riów, Komisja sporządza sprawozdanie, w którym uwzględnia również to, czy } \\
\text { deficyt publiczny przekracza publiczne wydatki inwestycyjne i uwzględnia } \\
\text { wszelkie inne istotne czynniki, w tym średniookresową sytuację gospodarczą } \\
\text { i budżetową państwa członkowskiego }\end{array}$ \\
\hline Art. 126 ust. 4 & $\begin{array}{l}\text { Komitet Ekonomiczno-Finansowy wydaje opinię w odniesieniu do sprawo- } \\
\text { zdania Komisji }\end{array}$ \\
\hline Art. 126 ust. 5 & $\begin{array}{l}\text { Jeżeli Komisja uzna, że w państwie członkowskim istnieje nadmierny deficyt } \\
\text { lub taki deficyt może nastąpić, kieruje opinię do danego państwa i informuje } \\
\text { o tym Radę }\end{array}$ \\
\hline Art. 126 ust. 6 & $\begin{array}{l}\text { Rada stwierdza, czy w danym państwie członkowskim istnieje nadmierny } \\
\text { deficyt }\end{array}$ \\
\hline Art. 126 ust. 7 & $\begin{array}{l}\text { Jeżeli Rada stwierdzi istnienie nadmiernego deficytu w danym państwie, } \\
\text { kieruje do niego zalecenia w celu wyeliminowania deficytu w wyznaczonym } \\
\text { terminie }\end{array}$ \\
\hline Art. 126 ust. 8 & $\begin{array}{l}\text { W przypadku gdy Rada stwierdzi, że w odpowiedzi na jej zalecenia żadne } \\
\text { skuteczne działanie nie zostało podjęte w oznaczonym terminie, może podać } \\
\text { zalecenia do publicznej wiadomości }\end{array}$ \\
\hline Art. 126 ust. 9 & $\begin{array}{l}\text { Jeśli dane państwo nadal nie realizuje zalecenia Rady, może ona wezwać je do } \\
\text { przyjęcia niezbędnych środków zaradczych }\end{array}$ \\
\hline Art. 126 ust. 11 & $\begin{array}{l}\text { Rada może nałożyć sankcje na państwo członkowskie, jeśli w odpowiedzi } \\
\text { na jej wezwanie nie podjęło ono niezbędnych środków w celu skorygowania } \\
\text { nadmiernego deficytu }\end{array}$ \\
\hline Art. 126 ust. 12 & $\begin{array}{l}\text { Rada uchyla wszystkie lub niektóre swoje decyzje i zalecenia, w miarę jak } \\
\text { nadmierny deficyt jest korygowany }\end{array}$ \\
\hline
\end{tabular}

Źródło: [Traktat o funkcjonowaniu Unii Europejskiej... 2016].

Kryteria poszanowania dyscypliny budżetowej zostały zdefiniowane w sposób następujący (art. 126 ust. 2 TFUE): 
- czy stosunek między planowanym lub rzeczywistym deficytem publicznym a PKB przekracza wartość odniesienia, chyba że stosunek ten zmniejszył się znacznie oraz w sposób stały i osiągnął poziom bliski wartości odniesienia lub przekroczenie wartości odniesienia ma charakter wyjątkowy oraz tymczasowy i stosunek ten pozostaje bliski wartości odniesienia;

- czy stosunek między długiem publicznym a PKB przekracza wartość odniesienia, chyba że stosunek ten zmniejsza się dostatecznie i zbliża się do wartości odniesienia w zadowalającym tempie.

Wartości odniesienia określone w art. 126 ust. 2 TFUE są następujące: $3 \%$ PKB dla kryterium deficytu publicznego i 60\% PKB dla kryterium długu publicznego [Protokół w sprawie procedury... 2016].

Sankcje przewidziane w art. 126 ust. 11 TFUE polegają na zastosowaniu jednego lub kilku spośród następujących środków: opublikowanie przez dane państwo członkowskie dodatkowych informacji przed emisją obligacji i papierów wartościowych, ponowne rozważenie przez Europejski Bank Inwestycyjny polityki udzielania pożyczek wobec danego państwa członkowskiego, zażądanie złożenia w Unii przez dane państwo członkowskie nieoprocentowanego depozytu stosownej wysokości aż do czasu, gdy nadmierny deficyt zostanie skorygowany, nałożenie grzywny w stosownej wysokości.

Część zapobiegawcza paktu stabilności i wzrostu ([Rozporządzenie Rady WE nr 1467/97], zmienione przez [Rozporządzenie UE nr 1177/2011]) wyjaśnia przepisy traktatu dotyczące procedury nadmiernego deficytu w odniesieniu do kilku kwestii. Z perspektywy unikania nadmiernego deficytu przez państwo członkowskie najważniejsze są wyjaśnienia dotyczące kryteriów poszanowania dyscypliny budżetowej oraz stosowania sankcji w ramach tej procedury.

$\mathrm{W}$ odniesieniu do pierwszej z tych kwestii wyjaśnienia są następujące: po pierwsze, przekroczenie wartości odniesienia przez deficyt publiczny ma charakter wyjątkowy oraz tymczasowy, gdy wynika ono z nadzwyczajnego i niezależnego od danego państwa członkowskiego zdarzenia, które wywiera istotny wpływ na saldo sektora instytucji rządowych i samorządowych lub w przypadku poważnego pogorszenia koniunktury gospodarczej; po drugie, w przypadku gdy dług publiczny przekracza wartość odniesienia, uznaje się, że relacja długu publicznego do PKB zmniejsza się dostatecznie i zbliża się w zadowalającym tempie do wartości odniesienia, jeśli w ciągu poprzednich trzech lat jej dystans względem wartości odniesienia zmniejszał się średnio w tempie jednej dwudziestej rocznie. Natomiast $\mathrm{w}$ odniesieniu do sankcji stosowanych w ramach procedury nadmiernego deficytu decyzja Rady o nałożeniu sankcji na państwo członkowskie zostaje podjęta w ciągu szesnastu miesięcy od daty przyjęcia sprawozdania przez Komisję. Termin ten ulega odpowiedniej zmianie w przypadku zmiany zalecenia 
lub wezwania. Z zasady nakładana jest grzywna. Rada może także zadecydować o zastosowaniu środków określonych w art. 126 ust. 11 TFUE.

W 2011 r. Parlament Europejski i Rada przyjęły nowe przepisy w celu skuteczniejszego egzekwowania nadzoru budżetowego w strefie euro [Rozporządzenie Parlamentu Europejskiego i Rady (UE) nr 1173/2011]. Rozszerzyły one zakres sankcji stosowanych w ramach tego nadzoru oraz wzmocniły rolę Komisji Europejskiej w ich nakładaniu. System sankcji obejmuje: 1) złożenie nieoprocentowanego depozytu w Komisji, jeśli dane państwo nie podjęło skutecznych działań zmierzających do osiągnięcia średniookresowego celu budżetowego; 2) złożenie oprocentowanego depozytu w Komisji, po stwierdzeniu istnienia w danym państwie nadmiernego deficytu; 3) nałożenie grzywny, jeśli dane państwo nie podjęło skutecznych działań w celu skorygowania nadmiernego deficytu; 4) nałożenie grzywny za manipulowanie danymi statystycznymi. Decyzje w sprawie nałożenia sankcji podejmuje Rada na zalecenie Komisji. Uznaje się jednak, że decyzja ta została podjęta przez Radę, jeżeli w terminie 10 dni od przyjęcia zalecenia Komisji Rada nie odrzuci go kwalifikowaną większością głosów.

Pakt fiskalny - część międzyrządowego Traktatu o stabilności, koordynacji i zarządzaniu w unii gospodarczej i walutowej [Treaty on stability... 2012] wzmocnił zmienione w 2011 r. przepisy paktu stabilności i wzrostu. W odniesieniu do jego części zapobiegawczej ustanowił on następujące zasady:

- saldo sektora instytucji rządowych i samorządowych musi być zrównoważone lub wykazywać nadwyżkę. Wymóg ten uważa się za spełniony, jeżeli jego roczne saldo strukturalne odpowiada celowi średniookresowemu dla danego państwa, przy czym dolny pułap deficytu strukturalnego wynosi $0,5 \%$ PKB,

- dane państwo może tymczasowo odejść od swojego celu średniookresowego lub ścieżki dostosowawczej prowadzącej do niego jedynie w wyjątkowych okolicznościach, oznaczających nadzwyczajne zdarzenie, na które dane państwo nie ma wpływu i które wywiera znaczący wpływ na sytuację finansową sektora publicznego, lub okresy znaczącego pogorszenia koniunktury. Tymczasowe odchylenia nie mogą zagrażać stabilności budżetowej w średnim okresie,

- w przypadku gdy dług publiczny w stosunku do PKB pozostaje wyraźnie poniżej $60 \%$ i gdy niskie jest ryzyko utraty długoterminowej stabilności finansów publicznych, dolny pułap średniookresowego celu budżetowego może odpowiadać deficytowi strukturalnemu wynoszącemu najwyżej $1 \%$ PKB,

- po stwierdzeniu znaczących odchyleń od celu średniookresowego lub ścieżki dostosowawczej prowadzącej do tego celu zostaje automatycznie uruchomiony mechanizm korygujący.

W swojej części naprawczej pakt fiskalny zobowiązuje państwo członkowskie objęte procedurą nadmiernego deficytu do wprowadzenia programu partnerstwa budżetowego i gospodarczego, zawierającego szczegółowy opis reform struktu- 
ralnych, które muszą zostać przyjęte i wdrożone w celu zapewnienia skutecznej i trwałej korekty nadmiernego deficytu. Programy te są zatwierdzane i monitorowane przez Radę i Komisję, zgodnie z obowiązującymi procedurami nadzoru w ramach paktu stabilności i wzrostu.

\section{Przestrzeganie numerycznych reguł paktu stabilności i wzrostu}

Przedmiotem numerycznych reguł paktu stabilności i wzrostu są przede wszystkim wymogi dotyczące osiągnięcia i utrzymania średniookresowego celu budżetowego oraz poszanowania dyscypliny budżetowej. Rozporządzenie Rady (UE) nr 1177/2011 wprowadza regułę, która uzupełnia wartość odniesienia dla kryterium długu publicznego. W przypadku gdy dług przekracza wartość odniesienia, uznaje się, że relacja długu publicznego do PKB zmniejsza się dostatecznie i zbliża $\mathrm{w}$ zadowalającym tempie do wartości odniesienia, jeśli w ciągu poprzednich trzech lat jej dystans względem wartości odniesienia zmniejszał się średnio w tempie jednej dwudziestej rocznie. Natomiast Rozporządzenie Parlamentu Europejskiego i Rady (UE) nr 1175/2011 określa numeryczną regułę dotyczącą wymogu osiągnięcia i utrzymania średniookresowego celu budżetowego, zgodnie z którą deficyt strukturalny nie przekracza $1 \%$ PKB.

Przedmiotem analizy przedstawionej w artykule jest poszanowanie numerycznych reguł paktu stabilności i wzrostu w polityce fiskalnej w strefie euro w latach 1999-2015 w odniesieniu do wymogu osiągnięcia i utrzymania średniookresowego celu budżetowego oraz wymogu poszanowania dyscypliny budżetowej związanego z kryterium deficytu publicznego. W badaniach przyjęto następujące miary zgodności polityki fiskalnej z numerycznymi regułami paktu stabilności i wzrostu: wskaźniki konkordancji oraz wskaźniki budżetowe stanowiące podstawę wymogów ustanowionych paktem. Wskaźniki konkordancji zostały zdefiniowane jako stosunek sumy lat, w których wymogi paktu zostały spełnione, do liczby lat okresu objętego badaniami. Wskaźnikami budżetowymi stanowiącymi podstawę wymogów ustanowionych paktem są: średnia arytmetyczna ogólnego salda budżetowego w odniesieniu do wymogu poszanowania dyscypliny budżetowej oraz średnia arytmetyczna salda budżetowego dostosowanego cyklicznie, w odniesieniu do wymogu osiągnięcia i utrzymania średniookresowego celu budżetowego. Dane dotyczące salda strukturalnego są dostępne dopiero od 2010 r. Miary zgodności polityki fiskalnej z numerycznymi regułami paktu stabilności i wzrostu zawiera tabela 2.

$\mathrm{Z}$ analizy tych wskaźników wynika, że stopień przestrzegania reguł paktu stabilności i wzrostu jest w strefie euro niski. W największej mierze odnosi to się do wymogu osiągnięcia i utrzymania średniookresowego celu budżetowego, 
Tabela 2. Wskaźniki zgodności polityki fiskalnej z regułami numerycznymi paktu stabilności i wzrostu

\begin{tabular}{|c|c|c|c|c|}
\hline \multirow{2}{*}{$\begin{array}{c}\text { Kraj } \\
\text { strefy euro }\end{array}$} & \multicolumn{2}{|c|}{$\begin{array}{l}\text { Reguły paktu dotyczące wymogu } \\
\text { osiągnięcia i utrzymania średnio- } \\
\text { okresowego celu budżetowego }\end{array}$} & \multicolumn{2}{|c|}{$\begin{array}{l}\text { Reguły paktu dotyczące wymogu } \\
\text { poszanowania dyscypliny budżetowe } \\
\text { - kryterium deficytu publicznego }\end{array}$} \\
\hline & $\begin{array}{c}\text { wskaźnik } \\
\text { konkordancji }\end{array}$ & $\begin{array}{l}\text { saldo budżetowe } \\
\text { dostosowane } \\
\text { cyklicznie }\end{array}$ & $\begin{array}{c}\text { wskaźnik } \\
\text { konkordancji }\end{array}$ & $\begin{array}{l}\text { ogólne saldo } \\
\text { budżetowe }\end{array}$ \\
\hline Belgia & 0,35 & $-2,0$ & 0,70 & $-1,9$ \\
\hline Niemcy & 0,41 & $-1,5$ & 0,58 & $-1,7$ \\
\hline Estonia & 0,70 & $-0,5$ & 0,94 & 0,3 \\
\hline Irlandia & 0,41 & $-4,3$ & 0,58 & $-4,2$ \\
\hline Grecja & 0,05 & $-7,1$ & 0,00 & $-8,0$ \\
\hline Hiszpania & 0,17 & $-3,1$ & 0,52 & $-3,6$ \\
\hline Francja & 0,00 & $-3,8$ & 0,29 & $-3,6$ \\
\hline Włochy & 0,11 & $-2,6$ & 0,47 & $-3,1$ \\
\hline Cypr & 0,11 & $-3,5$ & 0,41 & $-3,3$ \\
\hline Łotwa & 0,11 & $-2,6$ & 0,70 & $-2,6$ \\
\hline Litwa & 0,11 & $-2,7$ & 0,58 & $-2,9$ \\
\hline Luksemburg & 0,94 & 1,9 & 1,00 & 1,7 \\
\hline Malta & 0,05 & $-4,0$ & 0,41 & $-4,0$ \\
\hline Holandia & 0,47 & $-1,2$ & 0,76 & $-1,8$ \\
\hline Austria & 0,23 & $-2,3$ & 0,82 & $-2,4$ \\
\hline Portugalia & 0,00 & $-4,9$ & 0,11 & $-5,5$ \\
\hline Słowenia & 0,00 & $-4,0$ & 0,52 & $-3,9$ \\
\hline Słowacja & 0,00 & $-4,6$ & 0,47 & $-4,8$ \\
\hline Finlandia & 0,70 & 1,3 & 0,94 & 1,3 \\
\hline Średnia & 0,25 & $-2,8$ & 0,56 & $-2,8$ \\
\hline $\begin{array}{l}\text { Odchylenie } \\
\text { standardowe }\end{array}$ & 0,27 & 2,08 & 0,26 & 2,26 \\
\hline
\end{tabular}

Uwaga: wskaźniki salda budżetowego są średnimi z lat 1999-2015.

Źródło: opracowanie własne na podstawie [Cyclical Adjustment... 2016, s. 78; General Government Data... 2016, s, 140, 158].

istotnego dla zapobiegania wystąpieniu nadmiernego deficytu publicznego i dla możliwości stabilizacyjnego oddziaływania polityki fiskalnej na gospodarkę w ramach cyklu koniunkturalnego. Wskaźniki zgodności polityki fiskalnej z tym wymogiem są bardzo niskie. Średnia wskaźnika konkordancji wynosi zaledwie jedną czwartą jego maksymalnej wartości, a średnia salda budżetowego dostosowanego cyklicznie znacznie odbiega od deficytu bliskiego równowadze. Wymóg osiągnięcia i utrzymania średniookresowego celu budżetowego został spełniony 
w największej mierze w polityce fiskalnej Luksemburga, Finlandii i Estonii, przy czym pierwsze dwa państwa miały nadwyżkę budżetową, natomiast Estonia deficyt bliski równowadze. W latach 1999-2015 średniookresowego celu budżetowego nie osiągnięto we Francji, w Portugalii, w Słowenii i na Słowacji.

W odniesieniu do wymogu poszanowania dyscypliny budżetowej średnia wskaźnika konkordancji była ponaddwukrotnie większa od średniej wskaźnika konkordancji dotyczącego wymogu osiągnięcia i utrzymania średniookresowego celu budżetowego. Niemniej jednak w większości państw stosunek salda sektora instytucji rządowych i samorządowych do PKB przekraczał wartość odniesienia dla deficytu publicznego, przy czym przekroczenie to najczęściej nie było bliskie tej wartości. Tak jak w wypadku poprzedniego wymogu, poszanowanie dyscypliny budżetowej w polityce fiskalnej państw członkowskich jest bardzo zróżnicowane. W latach 1999-2015 jedynie w Luksemburgu nie wystąpił nadmierny deficyt publiczny. Pozostałe państwa nie uniknęły nadmiernego deficytu, przy czym w Grecji deficyt publiczny stale był nadmierny, a przekroczenie wartości odniesienia przez saldo budżetowe było największe. Ogólnie polityka fiskalna prowadzona w Luksemburgu, Finlandii i Estonii była najbardziej zgodna z wymogiem poszanowania dyscypliny budżetowej, natomiast w Grecji i Portugalii - najmniej.

\section{Analiza empiryczna antycyklicznego nastawienia polityki fiskalnej}

Polityka fiskalna jest jedynym makroekonomicznym instrumentem oddziaływania państwa na gospodarkę w strefie euro w celu jej ożywienia lub spowolnienia, zależnie od fazy cyklu koniunkturalnego. Znaczenie jej funkcji stabilizacyjnej jest tym większe, im bardziej gospodarka jest narażona na szoki asymetryczne, zwłaszcza na szoki popytowe, których skutki nie mogą być ograniczone za pomocą jednolitej polityki monetarnej. Stabilizowanie gospodarki wymaga, aby polityka fiskalna ograniczała wahania koniunkturalne. Jej nastawienie (fiscal stance - wpływ fiskalny) powinno być antycykliczne, a zatem w fazie silnego przegrzania koniunktury powinna być ona restrykcyjna, natomiast podczas recesji lub w przypadku niskiego poziomu realnego PKB w stosunku do jego poziomu potencjalnego - ekspansywna.

Tradycyjnie nastawienie polityki fiskalnej określa się na podstawie zmian pierwotnego salda budżetowego dostosowanego cyklicznie (cyclically-adjusted primary budget balance - CAPB) [Public Finances... 2006] lub salda budżetowego dostosowanego cyklicznie [Alesina i Perotti 1995, Mourre, Astarita i Princen 2014]. W 2013 r. Komisja Europejska zaproponowała nowy wskaźnik nastawienia polityki fiskalnej, mianowicie wskaźnik dyskrecjonalnego wysiłku fiskalnego 
(discretionary fiscal effort-DFE) [Public Finances... 2013]. Wskaźnik ten lepiej odzwierciedla działania dyskrecjonalne podejmowane w ramach polityki fiskalnej. Bazy danych Komisji Europejskiej nie zawierają jednak wskaźnika DFE.

Określając nastawienie polityki fiskalnej, przyjęto wskaźnik zmian pierwotnego salda budżetowego dostosowanego cyklicznie wyrażonego w procentach potencjalnego PKB. Zmiany tego wskaźnika mają charakter antycykliczny, jeżeli został spełniony jeden z dwóch następujących warunków: zmiany CAPB są dodatnie, jeżeli luka produktowa jest dodatnia; zmiany CAPB są ujemne, jeżeli luka produktowa jest ujemna. Aby określić antycykliczne nastawienie polityki fiskalnej, przyjęto również założenie, że bezwzględne zmiany CAPB muszą wynieść co najmniej 0,2\% potencjalnego PKB. Tabela 3 przestawia okresy, w których realizowano antycykliczną politykę fiskalną w strefie euro.

Tabela 3. Antycykliczne nastawienie polityki fiskalnej w strefie euro w latach 1999-2015

\begin{tabular}{|c|c|c|}
\hline \multirow{2}{*}{ Kraj } & \multicolumn{2}{|c|}{ Okresy realizacji antycyklicznej polityki fiskalnej } \\
\hline & polityka ekspansywna & polityka restrykcyjna \\
\hline Belgia & 2003,2009 & 2001,2006 \\
\hline Niemcy & 2009 & $1999,2000,2011,2012$ \\
\hline Estonia & 1999,2011 & $2003,2004,2013,2014,2015$ \\
\hline Irlandia & 2009,2010 & $2000,2003,2004,2006$ \\
\hline Grecja & 2013,2015 & 1999, 2000, 2005, \\
\hline Hiszpania & 2009,2015 & $1999,2005,2006$ \\
\hline Francja & 2009 & $2001,2005,2006$ \\
\hline Włochy & $2009,2014,2015$ & $2002,2004,2005,2007$ \\
\hline Cypr & $1999,2011,2014,2015$ & $2000,2006,2007$ \\
\hline Łotwa & 1999,2002 & 2003 \\
\hline Litwa & 2001,2011 & 2014,2015 \\
\hline Luksemburg & $2009,2010,2013,2014$ & $2000,2001,2005,2006,2007,2008$ \\
\hline Malta & 2010,2012 & $2000,2002,2005,2006$ \\
\hline Holandia & $2002,2009,2010,2013,2015$ & 1999,2000 \\
\hline Austria & 2009,2014 & $2000,2001,2007,2011,2012$ \\
\hline Portugalia & $2004,2009,2010,2014$ & $1999,2002,2005$ \\
\hline Słowenia & 1999, 2011, 2013 & 2002,2005 \\
\hline Słowacja & $\begin{array}{c}2000,2002,2004,2005,2009 \\
2010,2014,2015\end{array}$ & - \\
\hline Finlandia & $\begin{array}{c}2002,2003,2004,2009,2010 \\
2012,2013,2014\end{array}$ & - \\
\hline Strefa euro & 2009,2019 & $2000,2006,2007$ \\
\hline
\end{tabular}

Źródło: opracowanie własne na podstawie: http://ec.europa.eu/economy_finance/ameco/user/serie/ ResultSerie.cfm (data dostępu: 26.09.2016). 
Zgodność nastawienia polityki fiskalnej z cyklem koniunkturalnym mierzono dwoma wskaźnikami: wskaźnikiem konkordancji zmian CAPB z dodatnim lub ujemnym poziomem luki produktowej oraz współczynnikiem korelacji między zmianami CAPB a luką produktową. Luka produktowa została wyrażona w procentach potencjalnego PKB. Wskaźnik konkordancji zdefiniowano jako stosunek sumy lat okresu, podczas którego nastawienie polityki fiskalnej było antycykliczne, do sumy lat okresu objętego badaniami. Wyniki badań w odniesieniu do tej zgodności przedstawia tabela 4.

Tabela 4. Wskaźniki zgodności polityki fiskalnej z cyklem koniunkturalnym

\begin{tabular}{|l|c|c|}
\hline \multicolumn{1}{|c|}{$\begin{array}{c}\text { Kraj } \\
\text { strefy euro }\end{array}$} & $\begin{array}{c}\text { Wskaźnik konkordancji } \\
\text { zmian CAPB z dodatnim } \\
\text { lub ujemnym poziomem luki } \\
\text { produktowej }\end{array}$ & $\begin{array}{c}\text { Współczynnik korelacji } \\
\text { zmian między zmianami } \\
\text { CAPB a luką produktową }\end{array}$ \\
\hline Belgia & 0,29 & 0,19 \\
\hline Niemcy & 0,35 & 0,00 \\
\hline Estonia & 0,41 & $-0,58$ \\
\hline Irlandia & 0,35 & $-0,07$ \\
\hline Grecja & 0,29 & $-0,24$ \\
\hline Hiszpania & 0,29 & $-0,31$ \\
\hline Francja & 0,24 & $-0,44$ \\
\hline Włochy & 0,41 & $-0,24$ \\
\hline Cypr & 0,47 & $-0,12$ \\
\hline Łotwa & 0,18 & $-0,60$ \\
\hline Litwa & 0,24 & $-0,39$ \\
\hline Luksemburg & 0,59 & 0,02 \\
\hline Malta & 0,35 & $-0,50$ \\
\hline Holandia & 0,41 & $-0,32$ \\
\hline Austria & 0,41 & 0,10 \\
\hline Portugalia & 0,41 & $-0,19$ \\
\hline Słowenia & 0,29 & $-0,03$ \\
\hline Słowacja & 0,47 & $-0,20$ \\
\hline Finlandia & 0,53 & 0,33 \\
\hline Średnia & 0,37 & $-0,17$ \\
\hline Odchylenie standardowe & 0,12 & \\
\hline & & 0,25 \\
\hline
\end{tabular}

Uwaga: CAPB - pierwotne saldo budżetowe dostosowane cyklicznie wyrażone w procentach potencjalnego PKB (średnia z lat 1999-2015).

Źródło: opracowanie własne na podstawie: http://ec.europa.eu/economy_finance/ameco/user/serie/ ResultSerie.cfm (data dostępu: 26.09.2016). 
Z analizy wskaźników zgodności polityki fiskalnej z cyklem koniunkturalnym wynika, że w latach 1999-2015 nastawienie polityki fiskalnej było raczej procykliczne aniżeli antycykliczne. Średnia wskaźnika konkordancji była relatywnie niska, natomiast średnia współczynnika korelacji między zmianami CAPB a luką produktową była ujemna. Największą zgodnością z cyklem koniunkturalnym charakteryzowała się polityka fiskalna w Luksemburgu i Finlandii. Oba te państwa w największej też mierze wywiązywały się ze swoich zobowiązań wynikających z paktu stabilności i wzrostu.

Fazy cyklu koniunkturalnego przeważnie są dłuższe od faz nastawienia polityki fiskalnej. Ani polityka ekspansywna, ani polityka restrykcyjna nie może być prowadzona przez dłuższy okres ze względu na zagrożenia dla stabilności finansowej oraz na negatywne ich skutki dla alokacji zasobów oraz podziału dochodów. W strefie euro ekspansywna bądź restrykcyjna polityka fiskalna była prowadzona najdłużej przez trzy lata. Po okresie ekspansji następowała konsolidacja budżetowa, przy czym obie te fazy polityki fiskalnej tylko częściowo pokrywały się z fazami cyklu koniunkturalnego.

Możliwości stabilizacyjnego oddziaływania polityki fiskalnej na gospodarkę zależą od sytuacji budżetowej, zwłaszcza od wysokości długu publicznego. Przekroczenie wartości odniesienia dla kryterium długu publicznego zwiększa ryzyko niestabilności finansowej. Na początku funkcjonowania unii gospodarczej i walutowej w siedmiu państwach relacja długu publicznego do PKB była wyższa od wartości odniesienia. W latach 1999-2007 przekroczenie to zmniejszało się w strefie euro średnio o 5,7 pkt proc. PKB, przy czym tylko częściowo było ono wynikiem konsolidacji budżetowej. Koniunktura gospodarcza w tym okresie ogólnie sprzyjała obniżaniu tej relacji, nawet jeśli była prowadzona ekspansywna polityka fiskalna. W większości państw przeważały w tym okresie ujemne zmiany CAPB. Na istotny wysiłek konsolidacyjny zdobyły się jedynie Słowacja, Cypr, Luksemburg, Austria i Niemcy. Większość państw nie wykorzystała więc sprzyjających warunków cyklicznych do obniżenia relacji długu publicznego do PKB. Po 2007 r. nastąpiło silne pogorszenie koniunktury gospodarczej. W reakcji na kryzys gospodarczy i finansowy większość państw zdecydowała się na prowadzenie ekspansywnej dyskrecjonalnej polityki fiskalnej. Ekspansja budżetowa trwała stosunkowo krótko ze względu na silny wzrost długu publicznego wynikający zarówno ze wzrostu wydatków publicznych, jak i z największej po drugiej wojnie światowej recesji gospodarczej, która znacznie zmniejszyła dochody budżetowe. W efekcie nastąpiła zmiana nastawienia polityki fiskalnej z ekspansywnego na restrykcyjne, mimo że realny PKB był znacznie niższy od jego poziomu potencjalnego. 


\section{Współzależność między poszanowaniem reguł paktu stabilności i wzrostu a antycyklicznym nastawieniem polityki fiskalnej}

Analiza empiryczna dotycząca poszanowania numerycznych reguł paktu stabilności i wzrostu przez państwa członkowskie oraz antycyklicznego nastawienia ich polityki fiskalnej stworzyła warunki do zastosowania analizy korelacji w celu ustalenia współzależności między przestrzeganiem tych reguł a stabilizacyjnym oddziaływaniem polityki fiskalnej na gospodarkę. Przedmiotem badań jest korelacja między wskaźnikami stabilizacyjnej funkcji polityki fiskalnej a wskaźnikami spełniania dwóch podstawowych wymogów paktu stabilności i wzrostu: wymogu osiągnięcia i utrzymania średniookresowego celu budżetowego oraz wymogu poszanowania dyscypliny budżetowej. Współczynniki korelacji odnoszące się do tej współzależności zawiera tabela 5.

Tabela 5. Współczynniki korelacji między antycyklicznym nastawieniem polityki fiskalnej a poszanowaniem numerycznych reguł paktu stabilności i wzrostu

\begin{tabular}{|l|c|c|c|c|}
\hline \multirow{2}{*}{$\begin{array}{c}\text { Wskaźniki } \\
\text { stabilizacyjnej } \\
\text { funkcji polityki } \\
\text { fiskalnej }\end{array}$} & $\begin{array}{c}\text { Wymóg osiągnięcia i utrzymania } \\
\text { sredniookresowego celu } \\
\text { budżetowego }\end{array}$ & \multicolumn{2}{|c|}{$\begin{array}{c}\text { Wymóg poszanowania } \\
\text { dyscypliny budżetowej - kryterium } \\
\text { deficytu publicznego }\end{array}$} \\
\cline { 2 - 5 } & $\begin{array}{c}\text { wskaźnik } \\
\text { konkordancji }\end{array}$ & $\begin{array}{c}\text { średnia salda } \\
\text { budżetowego } \\
\text { dostosowanego } \\
\text { cyklicznie }\end{array}$ & $\begin{array}{c}\text { wskaźnik } \\
\text { konkordancji }\end{array}$ & $\begin{array}{c}\text { średnia ogólnego } \\
\text { salda budżeto- } \\
\text { wego }\end{array}$ \\
\hline $\begin{array}{l}\text { Zgodność zmian } \\
\begin{array}{l}\text { CAPB z dodat- } \\
\text { nim lub ujemnym } \\
\text { poziomem luki } \\
\text { produktowej }\end{array}\end{array}$ & 0,38 & 0,58 & 0,34 & 0,58 \\
\hline $\begin{array}{l}\text { Korelacja między } \\
\text { zmianami CAPB } \\
\text { a luką produk- } \\
\text { tową }\end{array}$ & 0,35 & 0,33 & 0,26 & 0,26 \\
\hline
\end{tabular}

Źródło: opracowanie własne na podstawie: http://ec.europa.eu/economy_finance/ameco/user/serie/ ResultSerie.cfm (data dostępu: 26.09.2016).

$\mathrm{Z}$ analizy korelacji wynika, że polityka fiskalna prowadzona zgodnie z wymogami paktu stabilności i wzrostu sprzyja stabilizacyjnemu jej oddziaływaniu na gospodarkę. Wartości współczynników korelacji między wskaźnikami antycyklicznego nastawienia polityki fiskalnej a wskaźnikami poszanowania numerycznych reguł paktu stabilności i wzrostu wynoszą w granicach 0,26-0,58. $\mathrm{Z}$ przeprowadzonych badań wynika także, że przestrzeganie wymogu dotyczącego osiągnięcia i utrzymania średniookresowego celu budżetowego sprzyja stabiliza- 
cyjnej funkcji polityki fiskalnej bardziej aniżeli unikanie nadmiernego deficytu. Utrzymywanie nadwyżki budżetowej względnie deficytu publicznego bliskiego równowagi budżetowej zwiększa pole manewru dla dyskrecjonalnych działań polityki fiskalnej.

Dodatnia korelacja między przestrzeganiem reguł paktu stabilności i wzrostu a stabilizacyjną funkcją polityki fiskalnej może wynikać zarówno z prowadzenia antycyklicznej polityki fiskalnej zgodnie z wymogami paktu, jak i z prowadzenia polityki procyklicznej z jednoczesnym naruszeniem jego reguł. $Z$ przeprowadzonych badań wynika jednoznacznie, że korelacja ta w większej mierze wynikała z połączenia polityki procyklicznej z niestosowaniem się do reguł paktu stabilności i wzrostu niż z prowadzenia polityki antycyklicznej zgodnie z jego regułami.

Czy wyniki analizy korelacji odzwierciedlają rzeczywistą współzależność między poszanowaniem reguł paktu stabilności i wzrostu a stabilizacyjną funkcją polityki fiskalnej? Badania dotyczyły lat 1999-2015, a więc stosunkowo krótkiego okresu. Odpowiadał on realnemu funkcjonowaniu europejskiej unii walutowej oraz paktu stabilności i wzrostu. Badania oparte na dłuższych szeregach czasowych z pewnością byłyby bardziej wiarygodne. Niemniej jednak wyniki analizy korelacji są zgodne $\mathrm{z}$ teorią ekonomii w odniesieniu do roli poszanowania dyscypliny budżetowej w stabilizowaniu gospodarki za pośrednictwem dyskrecjonalnych środków polityki fiskalnej.

\section{Podsumowanie}

Poszanowanie reguł paktu stabilności i wzrostu wzmacnia funkcję stabilizacyjną polityki fiskalnej. Potwierdzeniem tego są rezultaty przeprowadzonych badań, z których wynika, że istnieje dodatnia korelacja między przestrzeganiem numerycznych reguł paktu przez państwa członkowskie a antycyklicznym nastawieniem ich polityki fiskalnej.

Stopień poszanowania reguł paktu stabilności w strefie euro jest jednak relatywnie niski. W największej mierze odnosi to się do wymogu osiągnięcia i utrzymania średniookresowego celu budżetowego. Polityka fiskalna prowadzona zgodnie z tym wymogiem zwiększa swobodę wyboru dyskrecjonalnych środków budżetowych, zwłaszcza w celu ożywienia gospodarki, w przypadku znacznego pogorszenia koniunktury gospodarczej, bez ryzyka wystąpienia nadmiernego deficytu publicznego. W stosunku do poprzedniego wymogu, wymóg poszanowania dyscypliny budżetowej był lepiej spełniony w polityce fiskalnej państw członkowskich, niemniej jednak jej zgodność z tym wymogiem była niska. Stałe i poważne naruszenie tego wymogu w polityce fiskalnej wielu państw doprowadziło do silnego wzrostu ich długu publicznego, zagrażającego zarówno ich stabil- 
ności finansowej, jak i - ze względu na transgraniczne efekty zewnętrzne polityki fiskalnej - właściwemu funkcjonowaniu unii gospodarczej i walutowej.

Polityka fiskalna prowadzona przez państwa członkowskie miała bardziej charakter procykliczny aniżeli antycykliczny. Zamiast ograniczać wahania koniunkturalne, zwiększała je, zwłaszcza przez to, że prowadzono silnie ekspansywną politykę fiskalną w okresach, w których realny PKB znacznie przewyższał jego poziom potencjalny, stanowiąc tym samym zagrożenie dla stabilności cen i stabilności finansowej. Dodatnia korelacja między antycyklicznym nastawieniem polityki fiskalnej a przestrzeganiem numerycznych reguł paktu stabilności i wzrostu w większej mierze wynikała więc z prowadzenia polityki procyklicznej, $\mathrm{z}$ jednoczesnym naruszeniem tych reguł, aniżeli z odpowiedniego połączenia polityki antycyklicznej z wymogami dotyczącymi osiągnięcia i utrzymania średniookresowego celu budżetowego i poszanowania dyscypliny budżetowej.

\section{Literatura}

Alesina A., Perotti R. [1995], Fiscal Expansions and Fiscal Adjustment in OECD Countries, ,NBER Working Paper”, nr 5214.

Cyclical Adjustment of Budget Balances [2016], European Commission, Spring.

General Government Data. Part II: Tables by Series [2016], European Commission, Spring.

Mourre G., Astarita C., Princen S. [2014], Adjusting the Budget Balance for the Business Cycle: the EU Methodology, European Commission, „European Economy. Economic Papers", nr 536.

Protokół w sprawie procedury dotyczącej nadmiernego deficytu [2016], Dz.Urz. UE C 202, 7 czerwca.

Public Finances in EMU [2006], European Commission, „European Economy”, nr 3.

Public Finances in EMU - 2013 [2013], European Commission, „European Economy”, nr 4.

Rozporządzenie Parlamentu Europejskiego i Rady (UE) nr 1173/2011 z dnia 16 listopada 2011 r. w sprawie skutecznego egzekwowania nadzoru budżetowego w strefie euro [2016], Dz.Urz. UE L 306, 23 listopada.

Rozporządzenie Parlamentu Europejskiego i Rady (UE) nr 1175/2011 z dnia 16 listopada 2011 r. zmieniające Rozporządzenie Rady (WE) nr 1466/97 w sprawie wzmocnienia nadzoru pozycji budżetowych oraz nadzoru i koordynacji polityk gospodarczych [2011], Dz.Urz. UE L 306, 23 listopada.

Rozporządzenie Rady (UE) nr 1177/2011 z dnia 8 listopada 2011 r. zmieniające Rozporządzenie Rady (WE) nr 1467/97 z dnia 7 lipca 1997 r. w sprawie przyśpieszenia i wyjaśnienia procedury nadmiernego deficytu [2011], Dz.Urz. UE L 306, 23 listopada.

Rozporządzenie Rady (WE) nr 1466/97 z dnia 7 lipca 1997 r. w sprawie wzmocnienia nadzoru pozycji budżetowych oraz nadzoru i koordynacji polityk gospodarczych [1997], Dz.Urz. WE L 209, 2 sierpnia.

Rozporządzenie Rady (WE) nr 1467/97 z dnia 7 lipca 1997 r. w sprawie przyśpieszenia i wyjaśnienia procedury nadmiernego deficytu [1997], Dz.Urz. WE L 209, 2 sierpnia. 
Traktat o funkcjonowaniu Unii Europejskiej, wersja skonsolidowana 2016 [2016], Dz.Urz. UE C 202, 7 czerwca.

Treaty on stability, coordination and governance in the economic and monetary union (TSGC) [2012], March.

\section{The Stability and Growth Pact and Countercyclical Fiscal Policies in the Euro Area}

(Abstract)

The article assesses the role the Stability and Growth Pact (SGP) plays in stabilising the euro area economy. It examines the relationship between member states' compliance with the rules of the Pact and their attitude to countercyclical fiscal policy in the years 1999-2015. The study used descriptive statistics and correlation analysis, and arrives at the following conclusions: the level of member state compliance with the rules of the SGP is low, particularly in relation to the requirement to achieve and maintain the medium-term budgetary objective; the fiscal stance was pro-cyclical more often than countercyclical; there is a positive correlation between the perception of the Pact's numerical rules and the attitude of countercyclical fiscal policy.

Keywords: budgetary discipline, Stability and Growth Pact, fiscal policy, euro area. 